\title{
A SIMPLE SURGICAL APPROACH FOR CORRECTION OF DEFICIENT ALVEOLAR RIDGE FOR PROSPECTIVE FIXED PARTIAL DENTURE PATIENTS: A CLINICAL REPORT
}

\author{
Ambika Shrivastav ${ }^{1}$, Siddarth Gupta ${ }^{2}$ \\ ${ }^{1}$ Reader, Rishiraj Dental College, Bhopal, Madhya Pradesh, India. \\ ${ }^{2}$ Reader, Rishiraj Dental College, Bhopal, Madhya Pradesh, India.
}

Corresponding Author: Siddarth Gupt Mobile: +91-9993266900 sidd1982@rediffmaingen

Received: $23^{\text {rd }}$ Jan. 2014

Accepted: $5^{\text {th }}$ April 2014

Online: $25^{\text {th }}$ May 2014

\section{ABSTRACT}

Rehabilitation of patients with deficient Seibert's Class-III ridge mandibular ridge is always a challenge for a dentist. This article discusses the problems faced while rehabilitating such cases and also discusses the surgical and prosthetic management of one such case. A ridge augmentation procedure called as "Roll on Technique" was used to correct the contour of the ride. Fixed partial denture with altered framework design and tissue colored porcelain was used to complete the case. These simple but effective changes helped to give predictable esthetics with illusion of natural teeth

Keywords: Alveolar ridge, Augmentation, Fixed partial denture.

\section{INTRODUCTION}

Successful anterior fixed partial denture (FPD) must provide the patient with excellent long-term function and an attractive smile, which often is the primary motivating factor for patients to seek dental care. ${ }^{1}$ The edentulous area where a fixed prosthesis is to be provided is often overlooked during the treatment planning phase. This error is often recognized only when the fixed prosthesis is ready to be cemented in the patient's mouth. ${ }^{2}$

Proper treatment planning must include a careful analysis of the critical dimensions of the edentulous areas i.e mesiodistal width, occlusocervical distance, buccolingual diameter and location of the residual ridge. ${ }^{3}$

Alterations in ridge contour necessitate cosmetic compromises in prosthetic restorations. Attempts have been made to correct this problem by using various fixed and removable devices. In fixed prosthodontics, reconstruction of a deficient alveolar ridge is often managed by modifying the thickness and height of the pontic to compensate for the depression. The resultant overcontoured surface, however, is a potential food trap. In addition, the alveolar tissue above the pontic appears darker than the adjacent gingival tissue ("black triangles"). Food impaction, and percolation of saliva during speech has also been noticed. ${ }^{2}$ Phonetics and esthetics, are also affected with the latter being especially problematic in patients with a high smile line. ${ }^{4}$ Pink ceramic has also been added to the gingival parts of pontics to resemble lost gingival tissue, but the results of this technique have been less than ideal. ${ }^{5}$

Preprosthetic surgery with modified ridge lap pontics and fpd framework to augment the residual ridge is an effective method to counter this problem. ${ }^{6}$ Roll On technique for ridge augmentation is one such technique, where the epithelium is removed from the donor site, the tissue is thinned and then this de-epithelialized pedicle is raised and rolled upon it-self, thereby thickening the residual ridge.?

\section{Case Report: 1}

A 48 year old male patient reported with the chief complaint of missing lower anterior teeth since last 6 years. The patient did not present with any significant medical history. Patient was found to be using a transitional removable 
partial denture with which he was not comfortable. On intraoral examination it was found that $31,32 \& 41$ were missing and the residual alveolar ridge was found to be of Siebert's Class III type (Figure 1). After radiographic examination it was decided to use fpd to replace the missing teeth.

Conventional crown preparations to receive porcelain fused to metal retainers were carried out in relation to 33, $42 \& 43$. During trial of the temporary bridge black triangular spaces were noticed between the temporary bridge and residual ridge, which were very evident with the patient's smile. The patient was explained about this condition and was told about the ridge augmentation (periodontal surgical) options. ${ }^{8-15}$ It was finally decided to carry out the "Roll On Technique" soft tissue ridge augmentation procedure.

\section{PROCEDURE:}

1. After preparing the surgical site, a sub-epithelial incision was given using the No.15 blade on the labial surface of the edentulous site.

2. The epithelium was then removed by firm but slow dissection from the donor site (labial tissue) (Figure 2).

3. Then a full thickness incision was given to reflect the connective tissue upto the ridge crest.

4. The anterior part of the flap was rolled-on inside and placed in a labially prepared pouch, so that the de-epithelialized part touched the reflected part (Figure 3).

5. This flap was then firmly sutured (Figure 4).

6. Periopack (GC Company) was placed on to the donor site to prevent any secondary infection and trauma (Figure 5).

7. This donor site was left to slowly granulate in and fill.

8. The final fixed prosthesis was also modified for this case. In order to further cover the gap between the prosthesis and tissues gingival porcelain was used.

9. In order to adequately support the gingival porcelain slight change was done in the metal framework design and the connectors were extended more lingually in thin plate like fashion about $2 \mathrm{~mm}$ short of the alveolar ridge height.

10. This prosthesis was then cemented immediately after surgery to make sure that the tissue healing takes place in accordance with the ridge lap area of the fpd.

Oral hygiene instructions were given to the patient and oral hygiene maintenance aids were prescribed. Follow up was done after 6 months and this period was found to be uneventful and patient was quite satisfied (Figure 6).

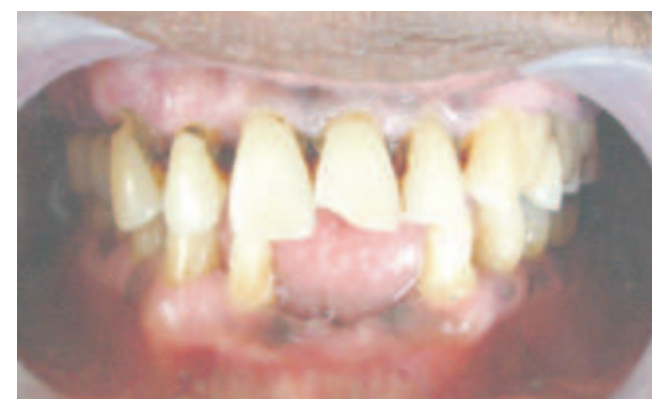

Figure 1: Partially edentulous patient with missing 31,32 \& 41 and Seibert's ClassIII ridge.

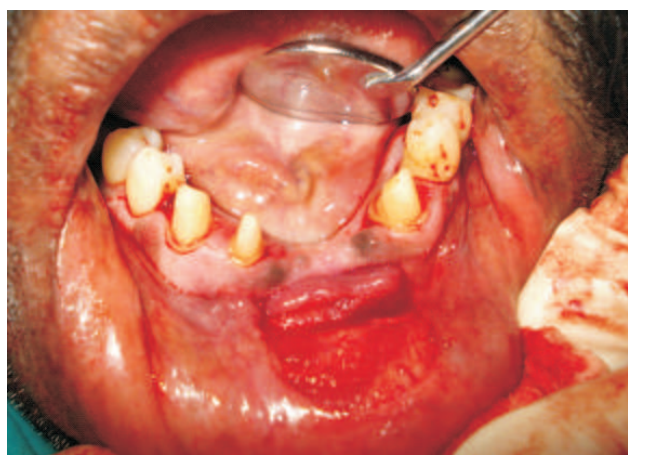

Figure 2: An sub-epithelial incision was given and initial de-epithelialization was done.

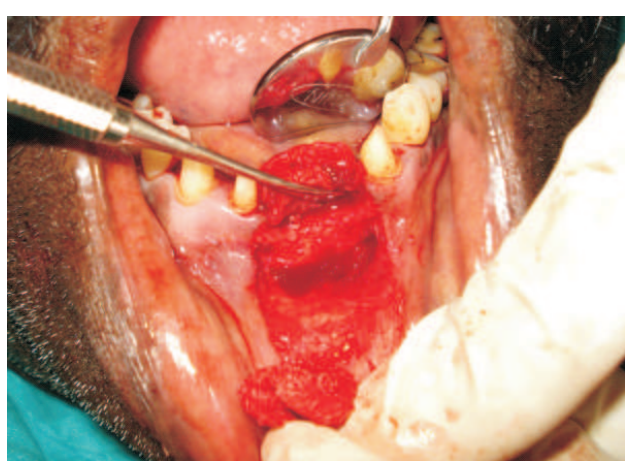

Figure 3: Full thickness incision was given to reflect the connective tissue upto the ridge crest and the anterior part of the flap was rolled-on inside.

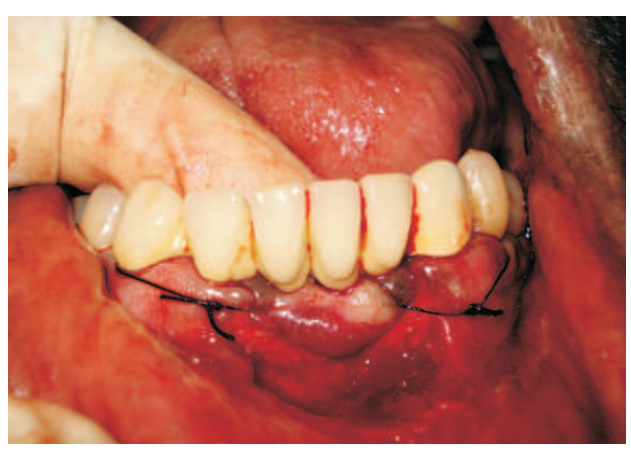

Figure 4: The flap was sutured in place and then the prosthesis was cemented. 


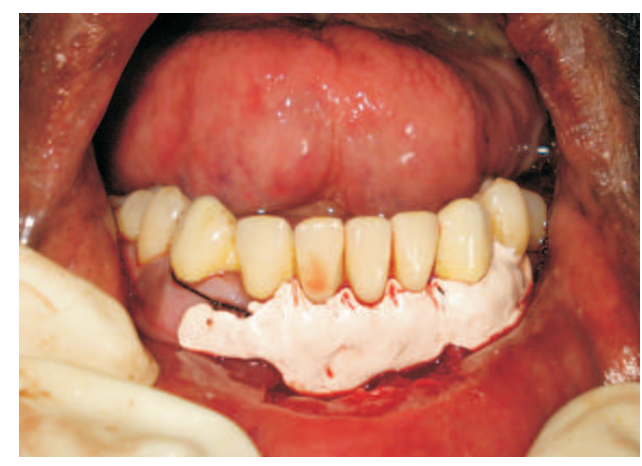

Figure 5: The site was covered with perio-pack.

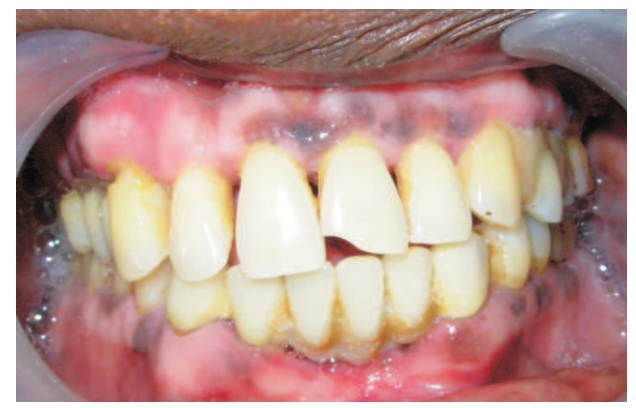

Figure 6: Six months post-operatively.

\section{DISCUSSION}

The interface between the soft and hard tissues and fixed partial denture is critical to achieving the desired esthetic results. In fact, correction of esthetic problems in patients has a positive effect on their self-esteem. An esthetically successful pontic should replicate the form, contours, incisal edge, gingival and incisal embrasures, and color of adjacent teeth. But pontic's simulation of a natural tooth is most often betrayed at the tissue-pontic interface.

The ultimate physical and anatomical form of the pontic recipient site results directly from the periodontal and dental state prior to extraction. Periapical and periodontal pathologies, trauma and the healing potential of the body are important factors in determining the future shape of the pontic recipient site.

The ridge after extraction in ideal conditions also is never found to be the same as that of pre-extraction conditions. The root prominence in the ridge generally resorbs during healing phase. The interdental papilla and the scalloped form of the marginal gingival no longer exists and the smooth tissue surface of the edentulous ridge does not mimic the pre-existing orange peel appearance of the gingiva. ${ }^{7,8}$

Siebert has classified such deformed residual ridges into three categories

- Class I defects -faciolingual loss of tissue width with normal ridge height

- Class II defects-loss of ridge height with normal ridge width

- Class III defects -a combination of loss in both dimensions ${ }^{4}$

The incidence of residual ridge deformity is a quite high incidence (91\%) following anterior tooth loss and majority of these are Class III defects. ${ }^{5}$ In addition another classification was proposed in which the ridge deformities are classified by assessing the depth of the defect in relation to the adjacent ridge. Mild: less than $3 \mathrm{~mm}$; moderate: from 3 to $6 \mathrm{~mm}$ and sever greater than $6 \mathrm{~mm}$.

\section{PROTOCOL FOR SURGICAL RECONSTRUCTION ${ }^{7}$}

The basic requirement for the success in the reconstruction of the collapsed ridge depends upon the following factors:

1. Understanding of the various types of defects.

2. Evaluation of the quality and quantity of the soft tissues in the edentulous area to allow elevation of the flap and avoid perforation.

3. Evaluation of the blood supply in the area.

4. Absence of periodontal pocket in the adjacent teeth.

5. Preservation of the marginal papillae of the adjacent teeth.

6. Evaluation of the quality and quantity of the grafting material from the donor site or the choice of implant material.

7. Evaluation of the number of surgical procedures required for the optimal results.

Repair of lost oral structures and prevention of unacceptable esthetic deformities are the goals of several current periodontal reconstructive procedures. Some of the most effective and commonly used are listed in Table1. 
Table 1

\begin{tabular}{|c|c|c|c|}
\hline \begin{tabular}{l|} 
S. \\
No.
\end{tabular} & Procedure & Advantages & Dis-advantages \\
\hline 1. & \begin{tabular}{|l|} 
Ridge Preservation \& \\
Augmentation \\
9 \\
Preservation of the ridge at \\
the time of extraction by \\
placing synthetic graft \\
material (Hydroxyapitite \\
granules) in the socket and \\
sealing the socket by either \\
gelatin or collagen material, \\
freezed dried cadaver skin \\
or free gingival graft or \\
partial thickness flap. \\
\end{tabular} & $\begin{array}{l}\text { - } \text { Reduces subsequent ridge } \\
\text { collapse } \\
\text { - } \\
\text { Reduces the number of } \\
\text { subsequent reconstructive } \\
\text { procedures. }\end{array}$ & $\begin{array}{l}\text { - Pre-surgical restorative } \\
\text { planning must be done before } \\
\text { the surgical procedure. } \\
\text { - Thorough surgical } \\
\text { debridement must be done in } \\
\text { areas of periapical pathosis }\end{array}$ \\
\hline 2. & $\begin{array}{l}\text { Onlay Graft }{ }^{4,10} \\
\text { This technique is more } \\
\text { predictable in smaller areas. }\end{array}$ & $\begin{array}{l}\text { - Increases the dimension of } \\
\text { the gingiva }\end{array}$ & $\begin{array}{l}\text { - Limited amount of donor } \\
\text { material } \\
\text { - Two surgical sites are } \\
\text { necessary } \\
\text { - Un-predictable post-operative } \\
\text { soft tissue shrinkage }\end{array}$ \\
\hline 3. & $\begin{array}{l}\text { Inlay Graft }{ }^{11,12,13} \\
\text { This technique is more } \\
\text { predictable in smaller areas. }\end{array}$ & $\begin{array}{l}\text { - Good color matching } \\
\text { - Improved vascularity } \\
\text { through the flap coverage } \\
\text { over the donor graft. } \\
\text { - Able to stabilize the donor } \\
\text { graft at the desired site. }\end{array}$ & $\begin{array}{l}\text { - Two surgical sites are } \\
\text { necessary } \\
\text { - Limited amount of donor } \\
\text { material } \\
\text { - Flap design, management and } \\
\text { transformation especially in the } \\
\text { interproximal papillary area. }\end{array}$ \\
\hline 4. & $\begin{array}{l}\text { Inlay-Onlay Graft }{ }^{14} \\
\text { This is a combination of the } \\
\text { above two techniques. }\end{array}$ & \multicolumn{2}{|c|}{ Advantages and disadvantages of each individual technique. } \\
\hline 5. & $\begin{array}{l}\text { Subperiosteal tunnel }{ }^{15} \\
\text { Generally used for seibert's } \\
\text { type-I defects also }\end{array}$ & $\begin{array}{l}\text { - Only one surgical site is } \\
\text { needed. } \\
\text { - There is abundant donor } \\
\text { material available. } \\
\text { (eg synthetic, alloplastic, } \\
\text { autogenous }\end{array}$ & $\begin{array}{l}\text {-Risk of loss of donor material } \\
\text { through sequestration. } \\
\text {-Flap perforation over thin } \\
\text { tissue bound to sharp alveolar } \\
\text { ridge deformity. } \\
\text {-Limited amount of } \\
\text { augmenatation because amount } \\
\text { of flap extension and no } \\
\text { verstality to manipulate the flap } \\
\text { to desired dimensions. }\end{array}$ \\
\hline
\end{tabular}




\begin{tabular}{|c|c|c|c|}
\hline 6. & $\begin{array}{l}\text { Anterior Advanced Flap/ } \\
\text { Coronally Positioned } \\
\text { Flap }{ }^{16} \\
\text { Most commonly used for } \\
\text { root coverage. } \\
\text { Can also be used to correct } \\
\text { ridge defects of small to } \\
\text { moderate dimensions }\end{array}$ & $\begin{array}{l}\text { - Maintains excellent } \\
\text { vascularity with } \\
\text { extended distance } \\
\text { transfer. } \\
\text { - Useful in combination } \\
\text { with implant }\end{array}$ & $\begin{array}{l}\text { - Extremely technique sensitive } \\
\text { - Secondary procedure because of } \\
\text { the new location of the the mueo } \\
\text { gingival junction. }\end{array}$ \\
\hline 7. & $\begin{array}{l}\text { Pantographic Lip } \\
\text { extension for ridge } \\
\text { Augmentation }{ }^{17} \\
\text { This technique allows for } \\
\text { flap coverage over } \\
\text { extensive defects. }\end{array}$ & $\begin{array}{l}\text { - Additional flap } \\
\text { availability in areas of } \\
\text { very shallow vestibular } \\
\text { depth. }\end{array}$ & $\begin{array}{l}\text { - Extremely technique sensitive } \\
\text { because of the surgical demands } \\
\text { required to manipulate two dis- } \\
\text { similar surfaces and achieve an } \\
\text { even junction. } \\
\text { - Eliminates or shallows the } \\
\text { vestibular depth. }\end{array}$ \\
\hline 8. & $\begin{array}{l}\text { Controlled tissue } \\
\text { Expansion }{ }^{18}\end{array}$ & $\begin{array}{l}\text { - Generates sufficient } \\
\text { tissue at the defect site. } \\
\text { - Avoids the need for } \\
\text { multiple phases of flap } \\
\text { transfer or a residual } \\
\text { defect with subsequent } \\
\text { secondary intention } \\
\text { healing. }\end{array}$ & $\begin{array}{l}\text { - Requires an altered clinical } \\
\text { judgemenin evaluation of the site } \\
\text { - Multiple visits for gradual } \\
\text { expansion of the expander } \\
\text { - Possible infection. } \\
\text { - Tissue necrosis } \\
\text { - Perforation } \\
\text { - Interference with the movement } \\
\text { of the lip }\end{array}$ \\
\hline
\end{tabular}

'Roll On technique' is an improved technique for localized ridge augmentation where in a de-epithelialized tissue pedicle is rolled over the residual ridge crest. The use of this technique is indicated for mild to moderate horizontal defects. Depending upon the thickness of the flap and the buccal extension of the recipient site, some improvement in vertical height can be obtained. For this technique tissue thickness is important in the donor site to allow sufficient blood supply and ease the elevation of the flap. This technique is also indicated for increasing the thickness in the first stage procedure of implants. This prevents tissue laceration with introduction of implant material and healing phase of the second stage procedure. ${ }^{19}$

The primary goal for such surgeries and subsequent restorations is restoration of lost function; esthetics and natural appearance. This goal can only be achieved if the final prosthesis is also modified according to the prevalent situation. Chiun-lin and Steven Liu in 1996 proposed a modified design for ovate pontic for deficient ridges. ${ }^{20}$ They suggested that this design helped to give excellent esthetics by providing good emergence profile and minimizing or eliminating black triangles. These pontics also provided good air and saliva seal and restored free gingival margin and interdental papilla. Jeff Thomas while reviewing Liu's modified ovate pontic suggested that the use of a modified ovate pontic may give the illusion of an interdental papilla, but it does not restore its decreased height or volume. ${ }^{21}$

An ideal ridgelap pontic must have smooth convex labial surfaces and smooth and open embrasures on the lingual side for easy oral hygiene maintenance. Another approach is to use pink porcelain to simulate the gingival tissues; however such pontics then have 
considerably increased tissue contact and require scrupulous plaque control for long-term success.

\section{CONCLUSION:}

These surgical techniques if used with good skills and clinical judgment can give good esthetic results; though they may not be of use in medically compromised patients or patients who are economically weak or patients who just don't have the will to undergo any kind of surgical treatment. These clinical reports suggests that a combination of a preprosthetic surgical procedure and modified fpd design can serve as a viable treatment option to provide excellent esthetics in patients with compromised anterior ridges.

\section{REFRENCES:}

1. McLean JW. The science and art of dental ceramics. Chicago (USA): Quintessence Publishing; 1980. Vol 2 p. 339.

2. Perel ML. A modified sanitary pontic. J Prosthet Dent 1972;28:589-92.

3. El-Askary AS, Pipco DJ. Autogenous and allogenous bone grafting techniques to maximize esthetics: a clinical report. J Prosthet Dent 2000;83:153-7.

4. Siebert JS et al. Reconstruction of deformed, partially edentulous ridges, using full thickness onlay grafts. Part. I. Technique and wound healing, Compend Contin Educ Dent 1983;4:437.

5. Abrams H, Kopczyk RA, Kaplan AL. Incidence of anterior ridge deformities in partially edentulous patients. J Prosthet Dent 1987;57:191.

6. Hawkins $\mathrm{CH}$ et al. Ridge contour related to esthetics and function. J Prosthet Dent 1991; 66:165.

7. Rufenacht CR. 'Ridge pontic relationship' in 'Fundamentals of esthetics'. Chicago (USA). Quintessence Publishing; 1980. Vol 1 p. 263-87.
8. Bahat O, Handlesman M. 'Esthetic reconstruction of alveolar ridge defects' in 'Advances in periodontics'edt. by Wilson TG,Kornman KS, Newman MC. Chicago (USA), Quintessence Publishing; Vol 1 p. 261-77.

9. Bahat $\mathrm{O}$, et al. Preservation of ridges utilizing hydroxyapatite. Int J Periodont Rest Dent1987;7(6):35.

10. Seibert JS. Reconstruction of deformed, partially edentulous ridges, using full thickness onlay grafts. Part II. Prosthetic/periodontal interrelationships. Compend Contin Educ Dent1983;4:549-62.

11. Langer B, Calagna L. The sub-epithelial connective tissue graft. J Prosthet Dent 1980;44:363-7.

12. Langer B, Calagna L. The subepithelial connective tissue graft. A new approach to the enhancement of anterior cosmetics. Int J Periodontics Restorative Dent 1982;2:23-33.

13. Garber DA, Rosenberg ES. The edentulous ridge in fixed prosthodontics. CompendContin Educ Dent 1981;2:212-23.

14. Seibert JS, Cohen D. Periodontal Considerations in preparation for fixed and removable prosthodontics. Dent Clin North Am 1987;31:529-555.

15. Allen EP, Gainza GS, Farthing GG, Et al. Improved technique for localized ridge agumentation. A report of 21 cases. J Periodontol 1985;56:195.

16. Bahat O, Handelsman M. Periodontal reconstructive flapsclassification and surgical considerations. Int J Periodont Rest Dent 1991;11:481-487.

17. Bahat O, Koplin M. Pantographic lip expansion and bone grafting for ridge agumentation. Int J Periodont Rest Dent 1989;9:345

18. Bahat O, Handlesman M. Controlled tissue expansion in reconstructive periodontal surgery. Int J Periodont Rest Dent 1991;11:25-30.

19. Abram L: Augmentation of the deformed residual edentulous ridge for fixed prosthesis. Compend Contin Edu Dent 1980;1:212.

20. Chiun-lin, Steven liu. Use of a modified ovate pontic in areas of ridge defects: A report of two cases. J Esthet Restor Dent 2004; 16:273-281.

21. Jeff Thomas. Commentary- Use of a modified ovate pontic in areas of ridge defects: A report of two cases. J Esthet Restor Dent 2004; 16:282-283. 